\title{
Sexual dimorphism in the mandible of the armadillo Chaetophractus villosus (Desmarest, 1804) (Dasypodidae) from northern Patagonia, Argentina
}

\author{
Squarcia, SM. ${ }^{\mathrm{a} *}$, Sidorkewicj, NS. ${ }^{\mathrm{a}}$, Camina, . $^{\mathrm{b}}$ and Casanave, EB. ${ }^{\mathrm{a}, \mathrm{c}}$ \\ ${ }^{a}$ Departamento de Biología, Bioquímica y Farmacia, \\ Universidad Nacional del Sur - UNS, \\ San Juan 670, 8000, Bahía Blanca, Argentina \\ ${ }^{b}$ Departamento de Matemática, Universidad Nacional del Sur - UNS, \\ Av. Alem 1253, 8000, Bahía Blanca, Argentina \\ ${ }^{\mathrm{c}}$ Consejo Nacional de Investigaciones Científicas y Técnicas - CONICET, \\ Buenos Aires, Argentina \\ *e-mail: squarcia@criba.edu.ar
}

Received April 19, 2007 - Accepted August 22, 2007 - Distributed May 31, 2009

(With 4 figures)

\begin{abstract}
The aim of this study was to study the sexual dimorphism in adult Chaetophractus villosus (Desmarest, 1804), from northern Patagonia, Argentina. Eight mandibular traits were measured in 37 males and 34 females. Univariate and multivariate morphometric analysis were applied to the data set. Results showed that $C$. villosus was sexually dimorphic, with higher absolute values corresponding to females. The total length of the mandible was the most important variable to discriminate sexes, followed by the height at the level of the last tooth and body length. The percentages of sex discrimination were high, as they were when a new sample (17 males, 13 females) was tested. Females have larger mandibles than males independently of their larger cranial size. They also showed a higher degree of correlation between variables, suggesting a more stable shape for the mandible than in males.
\end{abstract}

Keywords: Xenarthra, gender differences, jaw, morphometry, discriminant analysis.

\section{Dimorfismo sexual da mandíbula do tatu Chaetophractus villosus (Desmarest, 1804) (Dasypodidae) do norte da Patagônia Argentina}

\begin{abstract}
Resumo
O presente estudo examinou o dimorfismo sexual dos adultos de Chaetophractus villosus (Desmarest, 1804) do norte da Patagônia Argentina. Oito parâmetros mandibulares foram medidos em 37 machos e 34 fêmeas. Análises morfométricas univariada e multivariada foram aplicadas à série de dados. Os resultados mostraram que $C$. villosus apresenta dimorfismo sexual, com todos os valores absolutos mais elevados nas fêmeas. O comprimento total da mandíbula foi a variável mais importante para discriminar os sexos, seguidos pela altura no nível dos últimos dentes e pelo comprimento do corpo da mandíbula. As porcentagens de discriminação dos sexos foram elevadas, quando uma amostra nova (17 machos, 13 fêmeas) foi testada. As fêmeas têm as mandíbulas maiores que os machos, independentemente de seu tamanho cranial maior. Mostraram também um grau mais elevado de correlação entre variáveis, sugerindo uma forma mais estável para a mandíbula que nos machos.
\end{abstract}

Palavras-chave: Xenarthra, diferenças do sexo, mandíbula, morfometria, análise discriminante.

\section{Introduction}

Dasypodidae (Xenarthra) is a family of fossorial mammals, commonly known as armadillos, that originated in South America and radiated to Central and North America during the late Pliocene as the Panamanian land bridge neared completion (Webb, 1985). At present, eight living genera with twenty one probable species are known (Gardner, 2005), the majority of which are distributed in South America, particularly in Argentina, constituting an important part of the native fauna of the continent. They constitute a very interesting taxon from a scientific point of view, owing to peculiar characteristics concerning their anatomy (Wible and Gaudin, 2004; 
Squarcia et al., 2006), physiology (Casanave et al., 2005, 2006), evolutionary history and phylogenetic affinities (Delsuc et al., 2001; Gaudin, 2003).

Chaetophractus villosus (Desmarest, 1804), commonly known as the larger hairy armadillo, is the largest species of the genus. It is strictly confined to South America, being distributed from the Chaco of Paraguay and Argentina to the south-east of Chile and Argentina (Atalah, 1975; Wetzel, 1985; Deferrari et al., 2002).

The anatomical diversity of the mandibulodental complexes of mammals is large and probably reflects some adaptation to the diet (Langenbach and van Eijden, 2002), although there are also cases where diet and morphology do not clearly correlate (Landry, 1970). Some contributions are available about the morphology of the masticatory apparatus of several fossil xenarthrans, with consideration also of their dietary habits (Bargo et al., 2006; Vizcaíno et al., 2006). Within armadillos, there have been surprisingly few studies on the morphology and function of the mandible, despite the existing degree of morphological and ecological diversity among the species of the group. Vizcaíno et al. (2004) have performed morphofunctional and biomechanical studies of the masticatory adaptations in fossil representatives of this group, and concluded that some of them have evolved mechanical solutions that are neither shared by closely related taxa nor have current analogues that can be used as models in phylogenetic studies. In two living species related to C. villosus, Euphractus sexcinctus and Dasypus novemcinctus, Smith and Redford (1990) found that, although the morphology of the mandible reflects the dietary diversity of the group, it may be difficult to predict accurately behaviour or diet on the basis of morphology, even after comparison with other species with analogous morphological adaptations.

The intraspecific variation in the mandibular characters of $C$. villosus remains unexplored and their sexual dimorphism has only been studied for cranial characters. Squarcia and co-workers $(1993,1994,1999)$ reported gender differences in the skull of this species, with females being the larger sex. Therefore, there are good theoretical reasons to expect sexes to differ also in the size and/or shape of their mandibles.

The goal of the present work was to perform a univariate and multivariate study of the mandible of adult populations of $C$. villosus from northern Patagonia, Argentina, in an attempt to clarify if there exist gender differences. It is hoped that the results of this investigation will provide a more in-depth knowledge of this species, constituting a significant approach for future ecological studies.

\section{Material and Methods}

A total of 71 specimens of C. villosus (37 males and 34 females), coming from a radius of approximately $80 \mathrm{~km}$ around the city of Bahía Blanca $\left(38^{\circ} 42^{\prime} \mathrm{S}\right.$ and $\left.62^{\circ} 16^{\prime} \mathrm{W}\right)$, northern Argentine Patagonia, were used (Figure 1). All animals used were adults, which was determined because the sutures between basisphenoid and basioccipital and those of the occipital complex were not visible owing to a fusion of the bones (Morris, 1972).

All the specimens examined are kept at the Laboratory of Comparative Anatomy, Department of Biology, National University of the South, Argentina.

Eight mandibular dimensions (Figure 2) were recorded by means of a digital calliper $(0.01 \mathrm{~mm})$, as follows: total length (TL); length of the dental series (LDS); body length (BL); total height $(\mathrm{TH})$; condylar height $(\mathrm{CH})$; height at the level of the first tooth (HFT) and the last tooth (HLT); and ramus width (RW). Variables were

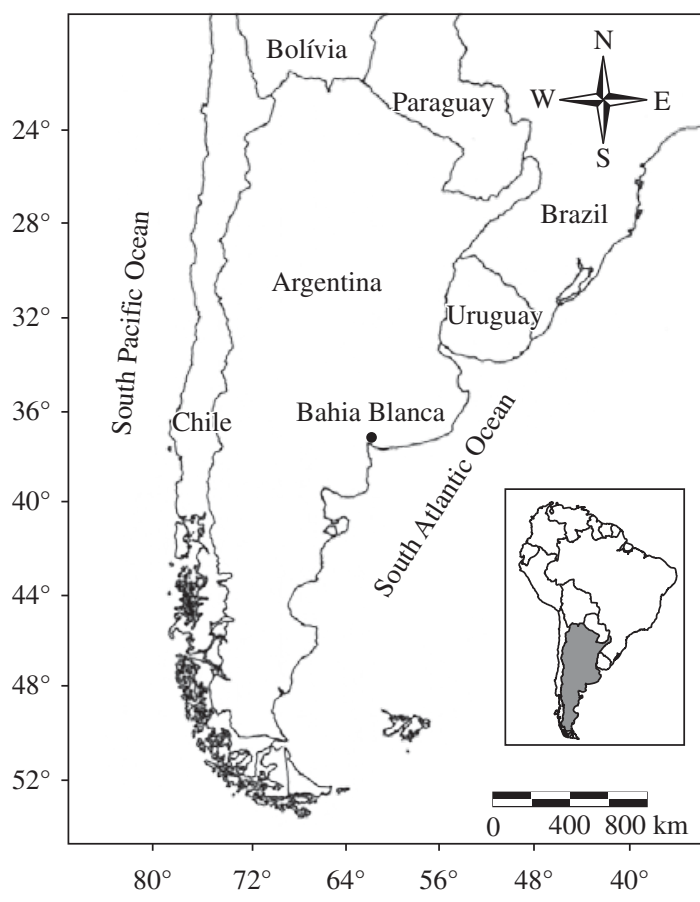

Figure 1. Map of the capture area of Chaetophractus villosus in southern Argentina.

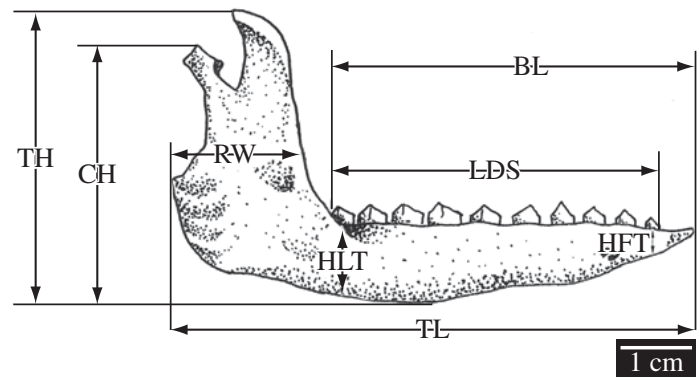

Figure 2. Mandible measurements taken in Chaetophractus villosus. Abbreviations of dimensions are explained in text. 
not log-transformed because there was a reasonable lineal dependence between them (Sprent, 1972).

Descriptive statistics including arithmetic means and standard error mean were calculated for the eight mandibular traits in both genders. Mean values were compared between males and females by means of the Student's two-tailed $t$-test ( $\mathrm{p} \leq 0.05$ ).

A linear discriminant analysis (LDA) was used to obtain a function to separate the sexes, and the canonical variables were also calculated. The selection of variables was performed by the stepwise method with a choice of F-to-enter value of 4.0 (BMDP7M, Jennrich and Sampson, 1983). To evaluate the accuracy of the method, the individuals were classified according to the function selected and the percentages of right assignment were calculated (Morrison, 1967). Finally, to test the obtained discriminant functions, 30 new adult animals (17 males, 13 females) coming from the same area of study were sexually classified.

Since sexual dimorphism was found, the correlation matrices of both genders were analysed separately by means of principal component analysis (PCA) to evaluate the relationship between the measured variables. The selected components (CP2 and CP3) were those whose eigenvalues were greater than one, following Kaiser criterion (Mardia et al., 1979).

An analysis of covariance, i.e., an analysis of variance applied to a linear regression model (ANCOVA, Snedecor and Cochran, 1980) was performed in both genders, to check the presumed relationships between the basal length of the skull (BLS; Squarcia et al., 1994) and the total length of the mandible (TL). These variables were chosen because they are considered as good estimators of the size of the skull and mandible, respectively, and they are practical traits to be measured. Differences were considered significant when $\mathrm{p} \leq 0.05$.

\section{Results}

Univariate statistics for mandibular measurements are listed in Table 1. These data showed that $C$. villosus is sexually dimorphic in every trait measured, with higher absolute values corresponding to females.

The variables selected according to their discriminant power were, sequentially: total length (TL), height at the level of the last tooth (HLT) and body length (BL). Taking into account one variable, the discriminant function obtained was: D1 $=-103.27+1.44 \mathrm{TL}$, where $\mathrm{D} 1<0$ for males and D1 $>0$ for females. The limit of classification (Lc) was TL $=71.87$ (Figure 3a). This function correctly classified $81.7 \%$ of the individuals, being $86.5 \%$ males $(n=32)$ and $76.5 \%$ females $(n=26)$. For two variables, the function was: $\mathrm{D} 2=-109.18+1.21 \mathrm{TL}+2.02$ HLT. The Lc was HLT $=53.95-0.60$ TL (Figure $3 b$ ). It correctly assigned $83.1 \%$ of the sample $(83.8 \%$ of the males, $\mathrm{n}=31$, and $82.4 \%$ of the females, $\mathrm{n}=28$ ). With three variables, the function was: $\mathrm{D} 3=-127.40+0.91 \mathrm{TL}+$ $2.51 \mathrm{HLT}+0.68 \mathrm{BL}$. In this case, the percentage of correct classification was $85.9 \%$ (89.2\% of the males, $\mathrm{n}=33$, and again $82.4 \%$ of the females, $\mathrm{n}=28$ ). The distribution of the individuals was represented in terms of the canonical variable, $\mathrm{V}=-55.23+0.39 \mathrm{TL}+1.09 \mathrm{HLT}+$ 0.29 BL (Figure 3c).

When the one-variable function was applied to the additional sample $(\mathrm{n}=30)$, it correctly assigned $82.3 \%$ of the males $(n=14)$ and $84.6 \%$ of the females $(n=11)$. Those percentages were also high with the other twoand three-variable functions, both in males (D2: $94.1 \%$, $\mathrm{n}=16 ; \mathrm{D} 3: 88.2 \%, \mathrm{n}=15)$ and females (D2: $84.6 \%$, $\mathrm{n}=11$; D3: $92.3 \%, \mathrm{n}=12$ ). According to these results, the validity of the functions was corroborated since the percentages of correct classification were similar to those obtained in the establishment of the functions.

The correlation structure of the mandibular traits was different in both genders. In general the correlations were low. Only 39 and $50 \%$ of the correlation coefficients obtained were significantly greater than zero in males and females, respectively ( $\mathrm{p} \leq 0.05)$. The only important correlation that maintained the same order of magnitude in both genders was $\mathrm{CH}-\mathrm{BL}$ ( $\mathrm{r}=0.652$ in males, $\mathrm{r}=0.645$ in

Table 1. Univariate statistics for mandibular measurements in total population and separate genders of Chaetophractus villosus.

\begin{tabular}{|c|c|c|c|c|}
\hline \multirow[t]{2}{*}{ Variable } & Total $(n=71)$ & Males $(n=37)$ & Females $(n=34)$ & \multirow[t]{2}{*}{$\mathbf{t}$} \\
\hline & Mean \pm SEM (Min-Max) & Mean \pm SEM (Min-Max) & Mean \pm SEM (Min-Max) & \\
\hline TL & $71.8 \pm 0.2(66.2-76.2)$ & $70.5 \pm 0.2(66.2-72.8)$ & $73.2 \pm 0.3(67.8-76.2)$ & $(* *)$ \\
\hline LDS & $44.8 \pm 0.1(41.9-47.6)$ & $44.2 \pm 0.1(41.9-45.8)$ & $45.5 \pm 0.2(43.1-47.6)$ & $(* *)$ \\
\hline $\mathrm{BL}$ & $50.9 \pm 0.2(44.7-53.6)$ & $50.1 \pm 0.2(44.7-52.1)$ & $51.8 \pm 0.2(45.6-53.6)$ & $(* *)$ \\
\hline TH & $39.9 \pm 0.1(33.4-43.3)$ & $39.0 \pm 0.2(33.4-40.7)$ & $40.8 \pm 0.2(34.6-43.3)$ & $(* *)$ \\
\hline $\mathrm{CH}$ & $35.4 \pm 0.1(27.2-38.5)$ & $34.7 \pm 0.2(28.2-36.3)$ & $36.2 \pm 0.3(27.2-38.5)$ & $(* *)$ \\
\hline HFT & $4.9 \pm 0.1(3.8-6.2)$ & $4.7 \pm 0.1(3.8-5.7)$ & $5.1 \pm 0.1(4.1-6.2)$ & $(* *)$ \\
\hline HLT & $11.0 \pm 0.1(9.0-12.7)$ & $10.7 \pm 0.1(9.0-12.7)$ & $11.4 \pm 0.1(9.3-12.6)$ & $(* *)$ \\
\hline RW & $21.5 \pm 0.1(18.4-23.5)$ & $21.0 \pm 0.1(18.4-22.0)$ & $22.0 \pm 0.1(18.7-23.5)$ & $(* *)$ \\
\hline
\end{tabular}

n: sample size; SEM: standard error mean; Min-Max: range; t: Student's t test for gender differences; and (**): $\mathrm{p} \leq 0.01$.

For abbreviations see text. 
females). On the other hand, the most correlated pair in the females (TL-LDS, $\mathrm{r}=0.850$ ) was uncorrelated in males $(r=0.341)$.

The PCA performed for independent genders showed that only $70.9 \%$ of the total variability in males, and $76.4 \%$ in females, were explained by the first three principal components. All the characters showed similar loadings on PC1, behaving as if they were the expression of a single size factor. This component accounted for $40 \%$ of the total variation in both genders owing to the low correlations of the matrices. The other components had correlations of different signs and magnitude and were interpreted as representing shape variation. PC2 in males contrasted HFT, HLT and TL against BL and LDS. In females, this component opposed $\mathrm{CH}$ and HFT against TL, LDS and RW. The third component, PC3, contrasted mainly the variables RW and TL versus
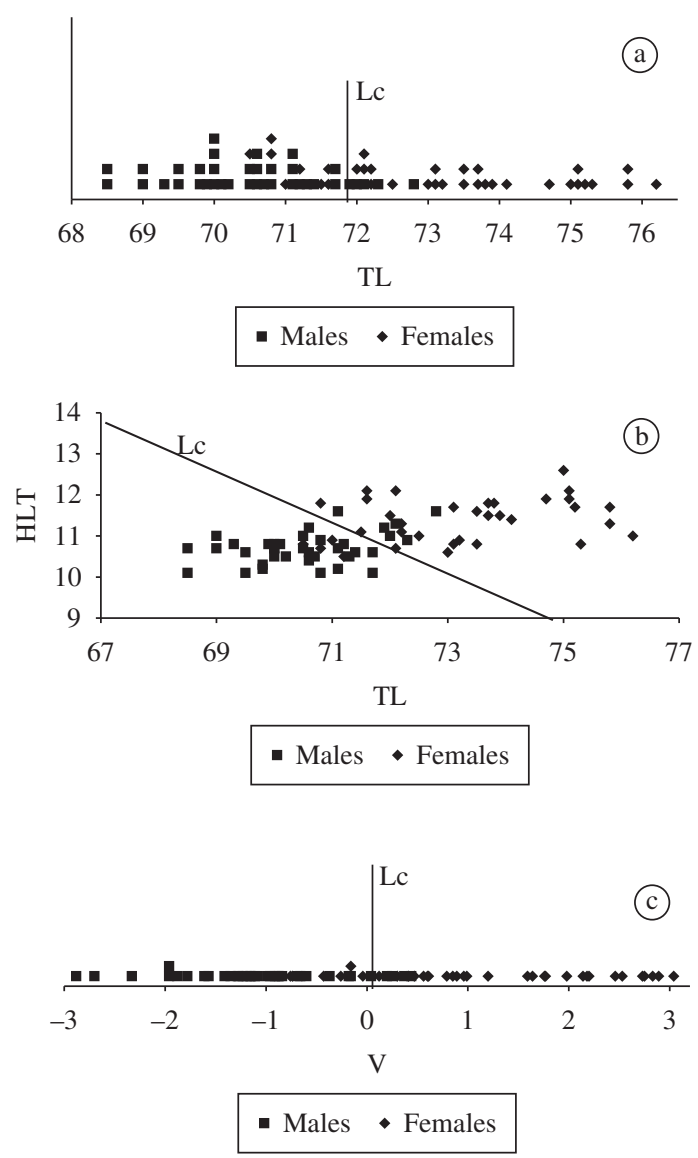

Figure 3. Distribution of the males $(\mathrm{n}=37)$ and females ( $\mathrm{n}=34$ ) of Chaetophractus villosus a) in terms of the total length of the mandible (TL); b) in the plane formed by TL and HLT (height of the mandible at the level of the last tooth); and c) in terms of the canonical variable $\mathrm{V}$ based on TL, HLT and body length BL. Lc: limit of classification.
LDS and HLT in males, whereas for females BL was contrasted against HLT.

The analysis of covariance between the length of the skull BLS (covariable) and TL showed that, size factor of the skull excluded, there are significant differences between sexes (Figure 4). This indicated that part of the differences in the mandible size between males and females are independent of differences in skull size between sexes.

\section{Discussion}

Size is an important factor contributing to the sexual dimorphism in several mammal groups, with males usually being the larger sex (Ralls, 1977; Wiig and Andersen, 1986; Ventura et al., 2002). The opposite situation is less frequent (Ralls, 1976; Holmes and Powell, 1994; Lammers et al., 2001).

According to Ralls (1977), the Edentata (at present Xenarthra) are a group with a small to moderate degree of sexual dimorphism, with males generally larger than females. Although there is a scarcity of evidence regarding individual components of the skeleton of this group, the univariate and multivariate analyses performed in the present study demonstrated a clear-cut sexual size dimorphism in the mandible of $C$. villosus, females being on average larger than males for all of the measured characters. This result is in agreement with the condition previously reported for the entire skull (Squarcia et al., 1994; 1999).

In the present study, two very important aspects of dimorphism in the mandible of C. villosus are disclosed. First, the mandible length was the most important variable in discriminating sexes. Second, females have mandibles with relatively longer and higher bodies than males.

The percentages of correct classification of the specimens obtained with the three discriminant functions were appropriate for sexual discrimination in the species under study. However, the election of a model with one,

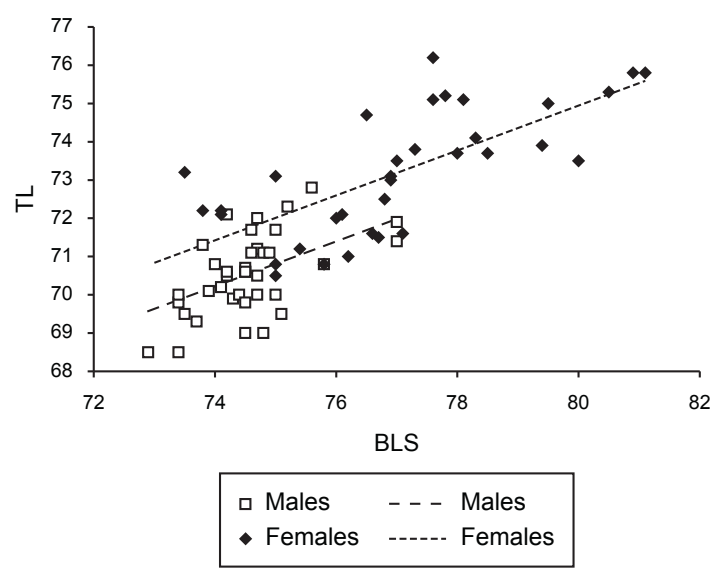

Figure 4. Relationship between the total length of the mandible (TL) and the basal length of the skull (BLS) for males $(\mathrm{n}=37)$ and females $(\mathrm{n}=34)$ of Chaetophractus villosus. 
two or three variables must be decided not only considering the biological meanings of the work but also from a practical point of view. On the other hand, it should be stressed that the discriminant technique is very sensitive to the statistical properties of those populations in which it is intended to be applied, since unknown intraspecific differences related with geographical variation could exist (López-Fuster et al., 2000; Sutton and Patterson, 2000; Popov and Ivanova, 2002; Mazák, 2004). Thus, the results obtained should always be considered with care when applied to classification of specimens of unknown sex coming from other areas. Moreover, since an agedependent factor could exist within natural populations and generate possible differentiation of groups (Baptista et al., 2000), the functions obtained should only be valid for adult animals.

As pointed out above, the main source of sexual dimorphism in the mandibles of $C$. villosus is a size factor, expressed through its total length. Such a factor covaried with the skull size, expressed through its basal length, and this explained a great portion of the total variability in the mandibles of both genders, i.e., larger female skulls will have naturally larger mandibles than the smaller male skulls. However, when size factor of the skull was removed, a per se greater size in the mandibles of the females became evident.

Gender differences in $C$. villosus were also obvious from the correlation structure of mandible dimensions. In general, the correlation values were low for both genders owing to only adult animals being used, so the rank of measured values for each of the involved variables was not as great as to generate strong correlations and, on the other hand, to the existence of changes in the mandibular shape. However in females, the higher degree of correlation between some length variables indicated a more stable shape for the mandible than in males. In the early stages of growth, mammals are characterized by the highest values of correlation coefficients between skull dimensions (Buchalczyk and Ruprecht, 1977; Kobryńczuk and Roskosz, 1980). The trend to a synchronism in the growth of the mandible, as a part of the skull, seems to be preserved in adult females of C. villosus to a larger extent than in males.

Generally, in those species where a sexual dimorphism at the skull level exists, it has been interpreted as a phenomenon of sexual selection in response to different ecological behaviour in both genders (Markowski and Østbye, 1992). Larger female skulls, for example, have been attributed to a differential use of niches in Chinchilla lanigera (Lammers et al., 2001), and to differences in resource partitioning in Martes sp. (Holmes and Powell, 1994). The variation in cranial size could also be related to adaptive and functional factors, as was well studied in carnivores, where several aspects inherent to the jaws are the most important factors affecting skull dimorphism (Wiig and Andersen, 1986).

Within armadillos, Smith and Redford (1990) found that if individuals are in a dynamic or variable ecologi- cal situation, analyses of form and function in the feeding apparatus must be performed with information on the full range of natural history data. Besides, it is unclear to what extent morphology imposes constraints on behaviour or ecology. The same authors point out the testing of hypotheses of constraint is difficult, if not impossible, in the absence of a situation where natural variation in diet or behaviour is present. It is necessary to emphasize that with the discriminant analysis, the factors responsible for the variability in the data-set could not be determined; also the significance of all the dimensions that contribute to sexual dimorphism could not be estimated (Petrov et al., 1992). Hence, to determine the pressures that account for the higher size observed in the mandible of the females of $C$. villosus is an extremely difficult task since this phenomenon could be the result of several factors that operate together. In this species, particularly, where the social structure and life history are poorly known, any interpretation aimed at explaining the observed dimorphism would be purely speculative. Further studies intended to amplify the knowledge of ecophysiological aspects of the species are of vital importance to elucidate this matter.

Acknowledgements - This study was supported by the Secretaría General de Ciencia y Tecnología, Universidad Nacional del Sur, Project 24/B122 and by the Agencia Nacional de Promoción Científica y Tecnológica de Argentina, PICTR 074/03.

\section{References}

ATALAH, GA., 1975. Presencia de Chaetophractus villosus (Edentata, Dasypodidae) nueva especie para la región de Magallanes, Chile. Anales del Instituto de la Patagonia, vol. 6, no. 1-2, p. 169-171.

BAPTISTA, TL., RICHARDSON, CS. and KUNZ, TH., 2000. Postnatal growth and age estimation in free-ranging bats: a comparison of longitudinal and cross-sectional sampling methods. Journal of Mammalogy, vol. 81, no. 3, p. 709-718.

BARGO, MS., TOLEDO, N. and VIZCAÍNO, SF., 2006. Muzzle of South American pleistocene ground sloths (Xenarthra, Tardigrada). Journal of Morphology, vol. 267, no. 2 , p. 248-263.

BUCHALCZYK, T. and RUPRECHT, AL., 1977. Skull variability of Mustela putorius Linnaeus, 1758. Acta Theriologica, vol. 22, no. 1-8, p. 87-120.

CASANAVE, EB., BERMÚDEZ, PM. and POLINI, NN., 2005. Haemostatic mechanisms of the armadillo Chaetophractus villosus (Xenarthra, Dasypodidae). Comparative Clinical Pathology, vol. 13, no. 4, p. 171-175.

2006. Principal coagulation factors and natural anticoagulants in the armadillo Chaetophractus villosus (Mammalia, Xenarthra, Dasypodidae). Comparative Clinical Pathology, vol. 14, no. 4, p. 210-216.

DEFERRARI, G., CAMILION, C., ESCOBAR, J. and LIZARRALDE, MS., 2002. Presencia de Chaetophractus villosus en Tierra del Fuego: nueva especie introducida. ¿Nuevo problema?. In Annals of the XVII Jornadas Argentinas de Mastozoología, Noviembre 18-20. Mar del Plata: Sociedad Argentina para el Estudio de los Mamíferos. p. 24. 
DELSUC, F., CATZEFLIS, FM., STANHOPE, MJ. and DOUZERY, EJ., 2001. The evolution of armadillos, anteaters and sloths depicted by nuclear and mitochondrial phylogenies: implications for status of the enigmatic fossil Eurotamandua. Proceedings of the Royal Society of London B, vol. 268, no. 1476 , p. $1605-1615$.

GARDNER, AL., 2005. Order Cingulata. In WILSON, DE. and REEDER, DM. (Eds.). Mammal species of the world. 3 ed. Baltimore: Johns Hopkins University Press. p. 94-99.

GAUDIN, TJ., 2003. Phylogeny of the Xenarthra (Mammalia). Senckerbergiana Biologica, vol. 83, no. 1, p. 27-40.

HOLMES, T. and POWELL, RA., 1994. Morphology, ecology, and the evolution of sexual dimorphism in North American Martes. In BUSKIRK, SW., HARESTAD, AS., RAPHAEL, MG. and POWELL, RA. (Eds.). Martens, sables and fishes: biology and conservation. Ithaca: Cornell University Press. p. $163-179$.

JENNRICH, R. and SAMPSON, P., 1983. Stepwise discriminant analysis. In DIXON, WJ. (Ed.). BMDP statistical software. Berkeley: University of California Press. p. 519-537.

KOBRYŃCZUK, F. and ROSKOSZ, T., 1980. Correlation of skull dimensions in the European bison. Acta Theriologica, vol. 25 , no. $22-31$, p. $349-363$.

LAMMERS, AR., DZIECH, HA. and GERMAN, RZ., 2001. Ontogeny of sexual dimorphism in Chinchilla lanigera (Rodentia: Chinchillidae). Journal of Morphology, vol. 82, no. 1 , p. 179-189.

LANDRY, SO., 1970. The Rodentia as omnivores. Quarterly Review of Biology, vol. 45, no. 4, p. 351-372.

LANGENBACH, GEJ. and van EIJDEN, TMGJ., 2002. Mammalian feeding motor patterns. American Zoologist, vol. 41 , no. 6 , p. 1338-1351.

LÓPEZ-FUSTER,MJ.,PÉREZ-HERNÁNDEZ,R.,VENTURA, J. and SALAZAR, M., 2000. Effect of environment on skullsize variation in Marmosa robinsoni in Venezuela. Journal of Mammalogy, vol. 81, no. 3, p. 829-837.

MARDIA, KV., KENT, JT. and BIBBY, JM., 1979. Multivariate analysis. London: Academic Press. 521p.

MARKOWSKI, J. and OSTBYE, E., 1992. Morphological variability of a root vole population in high mountain habitats, Hardangervidda, South Norway. Acta Theriologica, vol. 37, no. 1-2, p. 117-139.

MAZÁK, JH., 2004. On the sexual dimorphism in the skull of the tiger (Panthera tigris). Mammalian Biology, vol. 69, no. 6, p. 392-400.

MORRIS, P., 1972. A review of mammalian age determination methods. Mammal Review, vol. 2, no. 3, p. 69-104.

MORRISON, DF., 1967. Multivariate statistical methods. New York: Mc Graw Hill Book Company. 338p.

PETROV., NIKOLOV, H. and GERASIMOV, S., 1992. Craniometrical sex determination of wild cat Felis silvestris in Bulgaria. Acta Theriologica, vol. 37, no. 4, p. 381-396.

POPOV, VV. and IVANOVA, TI., 2002. Comparative craniometrical analysis and distributional patterns of mediumsized horseshow bats (Chiroptera: Rhinolophidae) in Bulgaria. Folia Zoologica, vol. 51, no. 3, p. 187-200.
RALLS, K., 1976. Mammals in which females are larger than males. Quarterly Review of Biology, vol. 51, no. 2, p. 245-276.

1977. Sexual dimorphism in mammals: avian models and unanswered questions. American Naturalist, vol. 111, no. 981 , p. $917-938$

SMITH, KK. and REDFORD, KH., 1990. The anatomy and function of the feeding apparatus in two armadillos (Dasypoda): anatomy is not destiny. Journal of Zoology, vol. 222, p. 27-47.

SNEDECOR, GW. and COCHRAN, W., 1980. Statistical methods. 7 ed. Ames: Iowa State University Press. 507p.

SPRENT, P., 1972. The Mathematics of size and shape. Biometrics, vol. 28 , no. 1, p. 23-37.

SQUARCIA, SM., CASANAVE, EB. and CIRONE, GR., 1993. Morfología craneana de Chaetophractus villosus (Mammalia, Dasypodidae). Iheringia, Série Zoologia, no. 75, p. 55-56.

1994. Morfometría craneana de Chaetophractus villosus (Mammalia, Dasypodidae). Anales del Museo de Historia Natural de Valparaíso, vol. 22, p. 103-106.

1999. Sexual dimorphism in Chaetophractus villosus (Mammalia, Dasypodidae) based on craniometrical characters. Anales del Museo de Historia Natural de Valparaíso, vol. 24, p. 91-94.

SQUARCIA, SM., SIDORKEWICJ, NS. and CASANAVE, EB., 2006. Cranial Osteology of the Armadillo Chaetophractus villosus (Mammalia, Xenarthra, Dasypodidae). International Journal of Morphology, vol. 24, no. 4, p. 541-543.

SUTTON, DA. and PATTERSON, BD., 2000. Geographic variation of the western chipmunks Tamias senex and T. siskiyou, with two new subspecies from California. Journal of Mammalogy, vol. 81, no. 2, p. 299-316

VENTURA， J., SALAZAR, M., PEREZ-HERNÁNDEZ, R. and LÓPEZ-FUSTER, MJ., 2002. Morphometrics of the genus Didelphis (Didelphimorphia: Didelphidae) in Venezuela. Journal of Mammalogy, vol. 83, no. 4, p. 1087-1096.

VIZCAÍNO, SF., BARGO, MS. and CASSINI, GH., 2006. Dental occlusal surface area in relation to body mass, food habits and other biological features in fossil xenarthrans. Ameghiniana, vol. 43, no. 1, p. 11-26.

VIZCAÍNO, SF., FARINA, RA., BARGO, MS. and DE IULIIS, G., 2004. Functional and phylogenetic assessment of the masticatory adaptations in Cingulata (Mammalia: Xenarthra). Ameghiniana, vol. 41, no. 4, p. 651-664

WEBB, SD.,1985. Late Cenozoic mammal dispersals between the Americas. In STEHLI, FG. and WEBB, SD. (Eds.). The Great American Interchange. New York: Plenum Press. p. 357-386

WETZEL, RM., 1985. Taxonomy and distribution of armadillos, Dasypodidae. In MONTGOMERY, GG. (Ed.). The evolution and ecology of armadillos, sloths and vermilingues. Washington: Smithsonian Institution Press. p. 23-46.

WIBLE, JR. and GAUDIN, TJ., 2004. On the cranial osteology of the yellow armadillo Euphractus sexcinctus (Dasypodidae, Xenarthra, Placentalia). Annals of Carnegie Museum, vol. 73, no. 3, p. $117-96$

WIIG, O. and ANDERSEN, T., 1986. Sexual size dimorphism in the skull of Norwegian lynx. Acta Theriologica, vol. 31, no. 12 , p. 147-155. 